\title{
Dampak Gempa Lombok dan Sumbawa 2018 terhadap Sumber Penghidupan dan Strategi Kelangsungan Hidup Keluarga Korban
}

\author{
Abdur Rofi ${ }^{1}$ dan Humam Zarodi ${ }^{2}$
}

${ }^{1}$ Departemen Geografi Lingkungan, Fakultas Geografi, Universitas Gadjah Mada, Yogyakarta Indonesia

${ }^{2}$ S2 Magister Manajemen Bencana Sekolah Pascasarjana, Universitas Gadjah Mada, Yogyakarta Indonesia

Email koresponden: abdurrofi@ugm.ac.id

Direvisi: 2019-08-30 Diterima: 2020-07-5

(C)2020 Fakultas Geografi UGM dan Ikatan Geograf Indonesia (IGI)

\begin{abstract}
Abstrak. Gempa Lombok dan Sumbawa 2018 mengakibatkan 564 kematian, 1.584 luka-luka, dan 396.032 warga mengungsi. Selain itu, gempa tersebut merusak 239.954 rumah. Studi ini dilakukan untuk mengkaji lebih jauh dampak gempa terhadap sumber penghidupan keluarga korban dan stategi kelangsung hidup mereka pasca gempa. Studi ini menggunakan data mentah dari survei rumah tangga korban yang dilakukan oleh UNDP. Jumlah sampel yang adalah 770 keluarga yang diambil secara sistematik random sampling dari daftar keluarga korban gempa di 7 kecamatan. Data dianalisis secara deskriptif kuantitatif. Studi ini menemukan bahwa gempa berdampak pada penghidupan $74,32 \%$ rumah tangga yang tersebar di seluruh kabupaten. Dampak paling signifikan adalah berkurangnya pendapatan, kehilangan pekerjaan, berkurangnya kemampuan fisik untuk bekerja, hilangnya pemasok dan pasar. Dampak tersebut bervariasi antar kabupaten/kota. Untuk mengatasi terganggunya sumber mata pencaharian, kegiatan/upaya keluarga korban antara lain meminjam, mengurangi konsumsi, menjual aset, dan berganti pekerjaan.
\end{abstract}

Kata Kunci: Gempa, sumber penghidupan, strategi kelangsungan hidup

Abstract. The 2018 Lombok and Sumbawa earthquakes resulted in 564 deaths, 1,584 injuries, and 396,032 residents displaced. Also, the earthquake damaged 239,954 houses. This study is conducting to examine further the impact of the earthquake on the livelihoods and livelihood strategy. This study uses raw data from the household survey. The total sample was 770 families taken by systematic random sampling from a list of earthquake victim families in 7 districts. Data were analyzed descriptively quantitatively. This study found that the earthquake's impact on livelihoods for $74.32 \%$ household spread across all districts. The most significant impact is reduced income, loss of employment, reduced physical ability to work, loss of suppliers and markets. These impacts vary between districts/cities. To overcome the disruption to their livelihood sources, the survivor's family's activities/efforts include borrowing, reducing consumption, selling assets, and changing jobs.

Keywords: Earthquake, livelihood, survival strategy

\section{PENDAHULUAN}

Pada tanggal 29 Juli 2018 pukul 06:47:38 WITA, gempa bumi tektonik berkekuatan $\mathrm{M}=6,4$ mengguncang pulau Lombok. Episenter terletak pada koordinat 8.35 LS dan 116.5 BT atau $47 \mathrm{~km}$ Timur Laut Kota Mataram pada kedalaman 24 $\mathrm{km}$ (AHA Centre, 2018). Guncangan gempa bumi ini terasa di daerah Lombok Utara, Lombok Barat, Lombok Timur, Lombok Tengah, Sumbawa Barat, dan Sumbawa Besar. Selanjutnya, pada tanggal 5 Agustus 2018 pukul 19:46:35 WITA gempa bumi $M=7,0$ kembali terjadi di Lombok. Episenter terletak pada koordinat 8.37 LS dan 116.48 BT pada jarak $18 \mathrm{~km}$ Barat Laut Kabupaten Lombok Timur dengan kedalaman $15 \mathrm{~km}$. Dengan episenter yang relatif sama dengan gempa bumi sebelumnya, BMKG menyatakan bahwa gempa bumi ini merupakan gempa bumi utama (Main Shock) dari rangkaian gempa bumi yang terjadi sebelumnya. Gempa susulan terjadi setelah gempa bumi utama dan dirasakan di beberapa wilayah di Propinsi NTB.
Bencana gempa bumi Lombok mengakibatkan 564 jiwa meninggal dunia, 1.584 orang luka-luka, dan 396.032 penduduk mengungsi. Kerusakan prasarana dan sarana skala besar seperti rumah penduduk 188.139 unit, gedung kantor, prasarana transportasi darat, prasarana sumber daya air, fasilitas kesehatan, pendidikan, tempat ibadah, hotel, toko dan berbagai fasilitas umum. Sektor yang paling terkena dampak dari gempa adalah pendidikan dan permukiman. Output kedua sektor tersebut turun masing-masing sebesar $16,79 \%$ dan $14,53 \%$ di tahun 2018. Sektor kesehatan juga mengalami penurunan output sebesar $4.93 \%$. Sektor pariwisata yang merupakan salah satu prioritas pembangunan terkena dampak terbesar keempat. Output sektor pariwisata turun hingga 4,89\% (Bappenas, 2018). Gambar 1. memperlihatkan sebaran kerusakan tempat tinggal karena gempa Lombok dan Sumbawa 2018.

Gempa bumi merupakan faktor penting yang memengaruhi mata pencaharian rumah tangga (Wei dkk., 

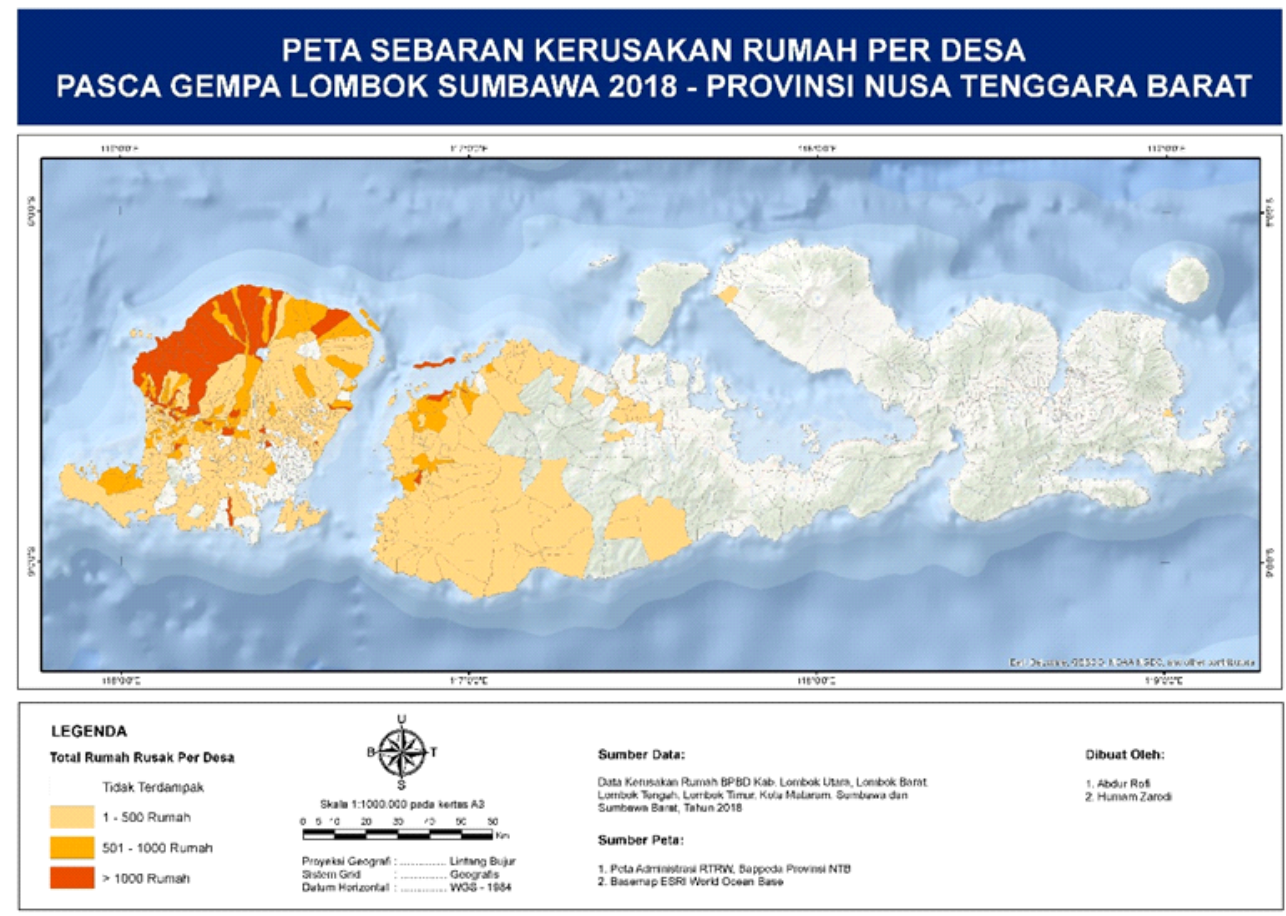

Gambar 1. Peta Sebaran Kerusakan Rumah Pasca Bencana Lombok dan Sumbawa 2018

2016). Bencana merusak pembangunan, menghancurkan usaha dan tenaga dan mampu meningkatkan kemiskinan (Sanderson, 2000). Di tingkat pemerintah daerah dan pusat, bencana juga merusak investasi dan sarana yang digunakan untuk pembangunan. Dalam kasus bencana Lombok, Bappenas (2018) memperkirakan adanya penurunan angka pertumbuhan ekonomi sebesar 1,5\%. Menurunnya pertumbuhan ekonomi ini diprediksi akan meningkatkan jumlah penganggur sebesar 180.000 orang pada tahun 2019. Angka pengangguran ini diperkirakan berasal dari sektor pariwisata, perdagangan, pertanian, dan industri. Pada bulan Maret 2018 angka pengangguran tercatat 14,75\% diperkirakan meningkat menjadi 15,88\% pada tahun 2019 . Peningkatan ini berdampak pada bertambahnya jumlah penduduk miskin sebanyak 806.430 jiwa pada tahun 2019 (Bappenas, 2018).

Literatur bencana menunjukan bahwa dampak sebuah bencana cenderung tidak merata tetapi dipengaruhi oleh intrekasi sosial dan pola-pola organisasional (Chou dkk., 2004). Dalam studi becana gempa di Yogytakarta 2006, Rofi (2006) menemukan bahwa korban meninggal cenderung mengelompok pada wilayah tertentu. Dalam menganggapi sebuah bencana, rumah tangga akan menggunakan berbagai sumberdaya yang dimilikinya. Dalam studi sumber penghidupan, sumber daya yang digunakan untuk melihat mata pencaharian telah dikelompokkan ke dalam kategori modal alam, manusia, keuangan, fisik dan sosial (R. Chambers \& Conway, 1992; Scoones, 1998).

Dalam konteks masyarakat berkembang dan dalam kasus -kasus di mana bencana berdampak pada pendapatan dan modal rumah tangga dengan mengganggu fungsi ekonomi lokal dan menghancurkan aset dan tanah yang produktif, pilihan strategi kelangsungan hidup rumah tangga seringkali terbatas. Sumber penghidupan dalam situasi seperti itu dipengaruhi oleh bahaya lingkungan (Wisner dkk., 2004). Oleh karena itu, situasi ini dapat mempengaruhi sejauh mana rumah tangga merasa harus memilih. Namun, proses kausal ini rumit, karena guncangan lingkungan berpotensi tidak hanya mendorong motivasi untuk berinovasi, tetapi juga membatasi kemampuan untuk melakukannya. Bencana yang mengejutkan berbagai sektor dapat berdampak pada mereka yang bergantung pada pekerjaan di sektor yang ada, serta mereka yang mengalami kehilangan modal alam dalam bentuk kerusakan pada lahan dan asset yang mereka miliki sendiri. Dalam kasus tertentu, rumah tangga terpaksa memilih untuk melakukan migrasi sebagai stertegi untuk kelangsungkan hidupnya (Loebach, 2016)

Strategi sumber penghidupan ini meliputi aspek pilihan atas beberapa sumber kehidupan yang ada di sekitar masyarakat. Semakin beragam pilihan sangat memungkinkan terjadinya strategi kehidupan. Penelitian ini bertujuan untuk melihat bagaimana dampak gempa terhadap sumber penghidupan keluarga korban bencana dan mempelajari strategi kelangsungan hidup keluarga korban terdampak gempa bumi Lombok dan Sumbawa 2018.

\section{METODE PENELITIAN}

Penelitian ini menggunakan sumber pencaharian (livelihood) sebagai obyek kajian. Sumber penghidupan telah menjadi obyek dari penelitian dan kebijakan penting selama beberapa dekade (R. Chambers \& Conway, 1992; de Haan \& Zoomers, 2005; Ellis, 2000; King, 2011; Knutsson, 2006). Konsep mata pencaharian telah menjadi tema utama dalam beberapa subbidang termasuk studi pembangunan (King, 2011).

Penelitian ini menggunakan pendekatan sustainable livelihood (mata pencaharian berkelanjutan) untuk mengkaji dampak gempa dan membantu menyusun rekomendasi untuk pemulihan sumber penghidupan. Pendekatan ini berusaha mencapai derajat pemenuhan kebutuhan sosial, ekonomi, dan ekologi secara adil dan seimbang. Pencapaian derajat kesejahteraan sosial didekati melalui kombinasi aktivitas dan utilisasi modal modal yang ada dalam tata nafkah (Ellis, 2000). Menurut kerangka mata pencaharian yang berkelanjutan, mata pencaharian adalah strategi yang digunakan oleh rumah tangga untuk memenuhi kebutuhan 
dasar mereka dalam kendala yang ditimbulkan oleh akses ke sumber daya (R. Chambers \& Conway, 1992; Scoones, 1998).

Ashley \& Hussein (2000) menjelaskan perbedaan antara pendekatan livelihood dengan yang konvensional adalah pada fokusnya, yang menekankan kepada kehidupan masyarakat. Hal ini dicirikan dengan pemahaman yang jelas bahwa well-being adalah tidak hanya tentang meningkatkan pendapatan tetapi juga dimensi kemiskinan yang harus disasar, termasuk tidak keamanan pangan, rasa tidak percaya diri, kekurangan aset fisik, dan ketidakberdayaan. Hal ini juga dipahami bahwa kemiskinan rumah tangga adalah dipengaruhi oleh banyak faktor, khususnya akses kepada aset dan pengaruh kebijakan dan kelembagaan. Penilaian dampak proyek harus didasarkan kepada pemahaman tujuan manusia maupun pada penjelasan bagaimana kehidupan mereka dibangun dan faktor-faktor yang secara penting mempengaruhi kemiskinan mereka.

Penelitian ini akan menggunakan konsep Sustainable Livelihood DFID (DFID, 1999) sebagai basis pengetahuan, yang digambarkan dalam kerangka kerja sebagaimana di bawah ini untuk melihat bagaimana pendekatan Sustainable Livelihood bekerja (gambar 2).

Penelitian ini menggunakan data mentah dari survei yang dilakukan oleh UNDP dan BPBD NTB pada bulan Januari-Maret 2019. Unit analisis penelitian ini adalah rumah tangga yang terdampak gempa di ketiga kabupaten yang ada. Untuk mengestimasikan rumah tangga yang terkena gempa, penelitian ini menggunakan rumah tangga yang tempat tinggalnya mengalami kerusakan karena gempa, meskipun boleh jadi terdapat rumah tangga yang rumah tangganya tidak rusak namun sumber penghidupannya terganggu. Hasil kajian BNPB dan BPBD menunjukkan terdapat 239.954 yang mengalami rusak, yang tersebar di 7 kabupaten/kota dengan. Dalam penelitian studi sumber penghidupan penduduk terdampak gempa LombokSumbawa 2018 ini, target populasi sebesar 239.954 rumah, dengan jumlah sampel 770 kepala rumah tangga, dengan tingkat kepercayaan 95\% dan confidence interval 5\% dan design effect 2, sampel diambil secara multistage random sampling dari data pemerintah korban gempa yang tempat tinggalnya mengalami rusak sedang dan berat di 7 (tujuh) kabupaten/ kota. Data tersebut dianalisis secara dekripsitif kuantitatif menggunakan tabel frekuensi, silang, dan grafik.

\section{HASIL DAN PEMBAHASAN}

Literatur bencana menunjukkan dampak dari sebuah bencana tidak merata tetapi dipengaruhi oleh interaksi sosial dan pola-pola organisasional (Chou dkk., 2004). Dalam kasus kematian karena gempa bumi misalnya bahwa kematian akibat gempa bumi dipengaruhi oleh karakteristik demografi, kondisi fisik, faktor-faktor struktural, dan faktor yang terkait dengan sifat kegempaan itu sendiri(Armenian dkk., 1997; Osaki \& Minowa, 2001; Ben Wisner dkk., 2014)

Faktor yang lain ditambahkan oleh Ellidokuz dkk. (2005) menunjukkan bahwa kesehatan fisik dan mental juga ikut mempengaruhi tanggapan seseorang secara cepat terhadap gempa. Di samping itu, kondisi sosial ekonomi juga ikut memainkan peranan penting. Seseorang dengan kondisi sosial ekonomi yang rendah berpotensi menghadapi risiko kematian akibat gempa. Kondisi sosial ekonomi ini terkait dengan rendahnya kualitas bangunan rumah dan kepadatan bangunan (Ellidokuz dkk, 2005). Pentingnya karakteristik individual dalam risiko dan bagaimana respons dalam menanggapi bencana pada bagian awal tulisan ini menjadi penting untuk dibahas di bagian awal sebelum membahas dampak bagi sumber penghidupan terhadap korban gempa Lombok-Sumbawa 2018.

Mayoritas pendidikan kepala keluarga di 7 (tujuh) kabupaten/kota lokasi terdampak gempa NTB adalah pendidikan rendah. Secara total di 7 (tujuh) kabupaten/ kota sebanyak $55 \%$ responden menyatakan tidak merasa ada dampak gempa terhadap kesehatan, sedangkan $45 \%$ responden menyatakan ada dampak gempa terhadap kesehatan. Gangguan kesehatan yang mendominasi kepada responden yang menyatakan ada dampak gempa terhadap kesehatan adalah penyakit infeksi seperti influenza, cacar air, leptospirosis dan lain-lain sebesar 28,3\%, kemudian masalah

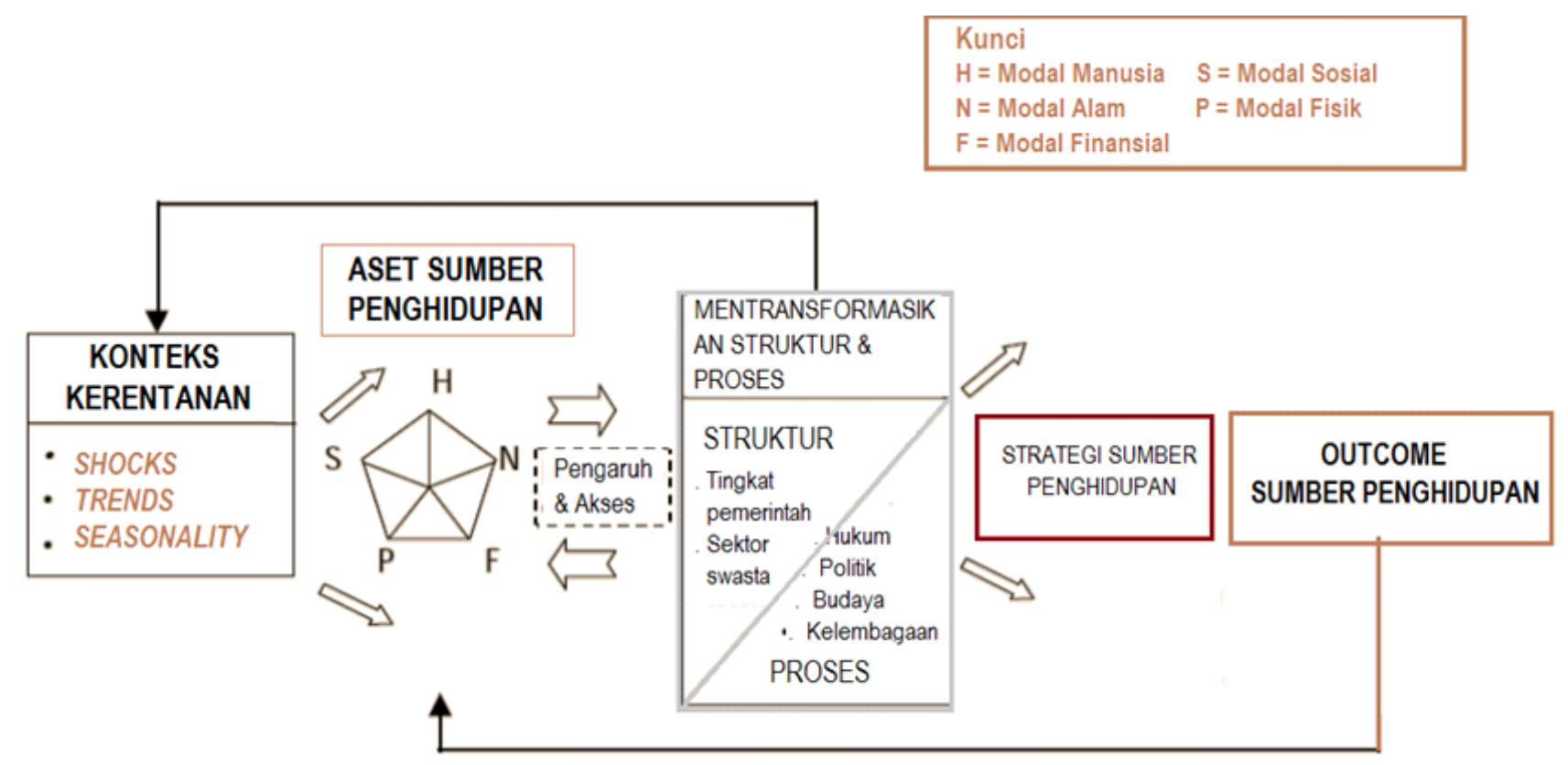

Gambar 2. DFID Sustainable Livelihood Framework Sumber: DFID (1999) 
kejiwaan seperti stres/depresi, trauma dan lain-lain) serta penyakit menular seperti diare, demam berdarah, malaria, ISPA dan penyakit mata sebesar $20 \%$. Secara keseluruhan di Provinsi Nusa Tenggara Barat, dampak gempa terhadap sumber penghidupan dirasakan oleh $74 \%$ rumah tangga, meskipun terdapat variasi antar kabupaten. Masyarakat Kabupaten Lombok Utara paling banyak terdampak yaitu 89,24 \% rumah tangga. Sementara Kabupaten Sumbawa Barat, masyarakatnya yang paling sedikit terdampak yaitu sekitar 33,90\% rumah tangga (Gambar 2).

Dampak bencana gempa terhadap sumber penghidupan lebih terasa di Kabupaten Lombok utara (89\%), Lombok Tengah (85\%), dan Lombok Timur (80\%), terutama di lokasi

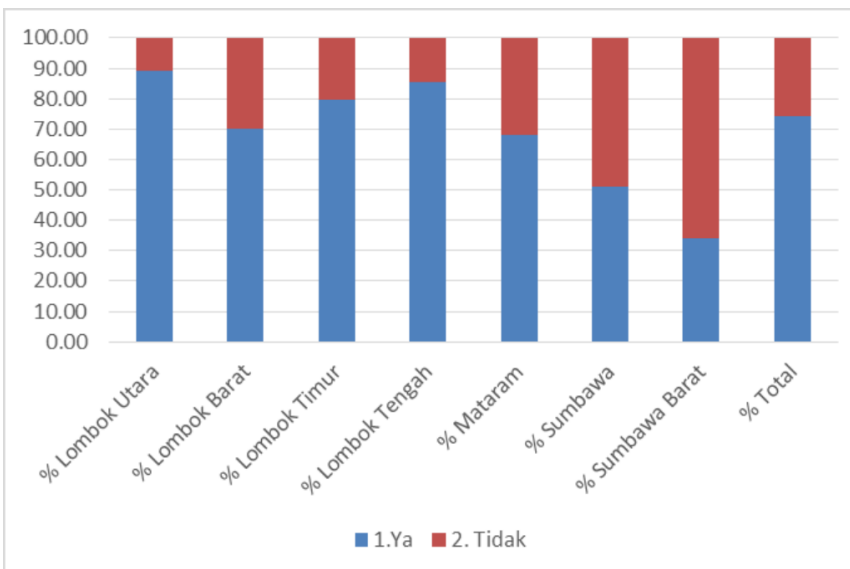

Sumber: Pengolahan Data Mentah, UNDP, 2019

Gambar 3. Dampak Gempa Terhadap Sumber Penghidupan di 6 kabupaten 1 kota di Provinsi NTB

di mana aktivitas ekonomi mengalami kerusakan. Sumber penghidupan juga sedikit terganggu, selain tempat untuk mencari nafkah terganggu juga waktu yang dipakai untuk perbaikan tempat tinggal, misalnya kebun dan sawah sebagai penyumbang ekonomi warga terbengkalai (tidak terawat) karena warga berkonsentrasi memperbaiki rumahnya. Sedangkan di Kabupaten Subawa dan Sumbawa Barat, warga di dua kabupaten ini paling sedikit merasakan dampak gempa terhadap sumber pendapatan yaitu hanya $51 \%$ warga di Kabupaten Sumbawa dan 34\% warga di Kabupaten Sumbawa Barat.

Rata-rata sumber pendapatan baik sebelum maupun setelah gempa yang paling dominan di Propinsi NTB yaitu dagang, pekerjaan tetap, hasil perikanan dan kiriman. Hampir semua sumber pendapatan menurun setelah gempa, tetapi setelah gempa sumber pendapatan justru naik yaitu kiriman. Sebelum gempa rata-rata pendapatan dari kiriman sebesar Rp. 995.786, setelah gempa naik menjadi Rp 1.026.285. Kenaikan kiriman ini terjadi di Kabupaten Lombok Timur, Kabupaten Lombok Tengah, Kota Mataram dan Kabupaten Sumbawa

Rumah tangga yang menyatakan ada dampak gempa terhadap sumber penghidupan, secara total di Propinsi NTB, sebanyak $50 \%$ mengalami berkurangnya pendapatan, sebanyak $23 \%$ kehilangan pekerjaan (sebagai pekerja/buruh) dan sebanyak $15 \%$ berkurangnya kemampuan fisik dan atau psikis untuk bekerja (Gambar 4).

Berkurangnya pendapatan rumah tangga dipengaruhi oleh beberapa faktor. Diantaranya karena kehilangan pekerjaan. Anggota keluarga untuk bekerja setelah gempa

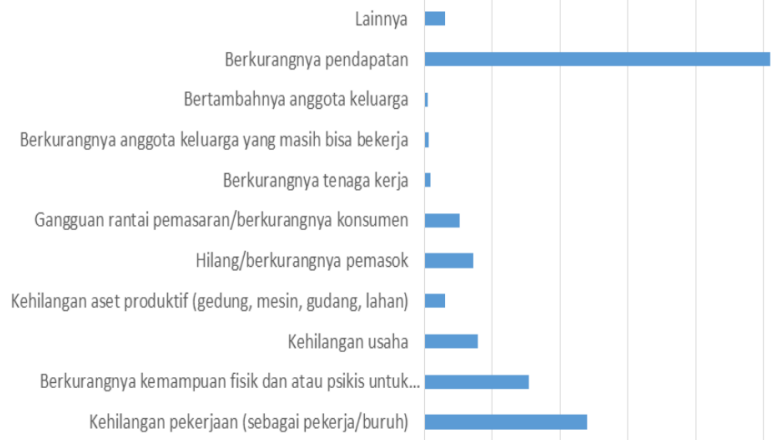

$\begin{array}{lllllll}0.00 & 10.00 & 20.00 & 30.00 & 40.00 & 50.00 & 60.00\end{array}$

Sumber: Pengolahan Data Mentah, UNDP, 2019

Gambar 4. Bentuk Dampak Gempa Terhadap Sumber

Penghidupan Keluarga (Jawaban Dapat Lebih Dari Satu)

mengalami penurunan sebesar $1,4 \%$ apabila dibandingkan dengan sebelum gempa. Meskipun demikian, persentase anak yang bekerja setelah gempa mengalami kenaikan. Hal ini disebabkan ada beberapa kepala keluarga dan pasangan kepala keluarga yang mengalami cacat karena gempa, sehingga tidak bisa bekerja lagi. Kemudian anak dari kepala keluarga maupun pasangan kepala keluarga yang mengalami cacat karena gempa terjun ke dunia kerja.

Penurunan anggota rumah tangga yang bekerja sebagian besar di sektor pariwsiata. Temuan ini sejalan dengan pendataan BPS (2019) yang menyebutkan tingkat Penghunian Kamar (TPK) hotel bintang pada bulan Desember 2018 sebesar 40,53 persen.Jika dibandingkan dengan TPK hotel bintang bulan Desember 2017 sebesar 50,05 persen berarti mengalami penurunan 9,52 poin. TPK Hotel Non Bintang bulan Desember 2018 hanya sebesar 24,01. Jika dibandingkan dengan bulan Desember 2017 mengalami penurunan sebesar 3,75 poin dari 27,76 persen.

Bagaimana rumah tangga mengatasi dampak gempa terhadap sumber penghidupan ?. Untuk mengatasi dampak gempa yang terjadi, sebagian besar rumah tangga berupaya untuk mengatasi dampak gempa terhadap sumber pendapatan (72,73 \%). Sedangkan sebanyak $27,27 \%$ rumah tangga tidak/ belum melakukan upaya untuk mengatasi dampak gempa. Beberapa cara dilakukan oleh responden untuk mengatasi dampak gempa. Cara yang paling banyak adalah dengan meminjam uang, mengurangi konsumsi, jual harta/ harta yang ada dan berganti pekerjaan. Tercatat sebanyak 40,57 \% keluarga korban meminjam yang, cara kedua adalah dengan mengurangi konsumsi $(24,14 \%)$, cara lainnya adalah dengan jual aset/ harta yang ada (11,56\%) dan berganti pekerjaan (10,75\%) (Gambar 5).

Di Kabupaten Lombok Timur, strategi mengatasi dampak gempa terhadap sumber pendapatan keluarga setelah gempa berupa meminjam uang paling tinggi apabila dibandingkan dengan kabupaten/ kota terdampak lainnya yaitu sebesar 62,5 \%, kemudian disusul Kota Mataram sebesar 50 \% dan Kabupaten Sumbawa sebesar 41,46 \%. Sedangkan mengurangi konsumsi paling banyak dilakukan responden di Kabupaten Sumbawa sebesar 46,34 \%, kemudian Kabupaten Sumbawa Barat sebesar 35,71 \% dan Kabupaten Lombok Barat sebesar 32,59 \% (Gambar 6). 
Temuan dari studi ini menunjukkan bahwa strategi yang paling banyak dipakai oleh rumah tangga dalam mengatasi gempa adalah berhutang, meskipun strategi ini tidak bisa dilakukan oleh semua keluarga. Hal ini terlihat bahwa terdapat keluarga mencoba mendapatkan pinjaman dari luar. Tercatat bahwa dari responden yang berusaha mendapatkan pinjaman mengalami kesulitan untuk mendapatkan pinjaman terutama di Kabupaten Lombok Utara, Kabupaten Lombok Barat, Kabupaten Lombok Timur dan Kota Mataram. Kesulitan ini di antaranya tidak adanya jaminan atau bunga yang terlalu tinggi. Dalam beberapa kasus, masyarakat juga malu jika mereka ketahuan berhutang. Namun di Kabupaten Sumbawa dan Kabupaten Sumbawa barat reponden yang akan meminjam uang tidak mengalami kesulitan .

Strategi kedua yang digunakan oleh rumah tangga yang terkena dampak adalah mengatur pengeluaran. Terlihat bahwa keluarga keluarga yang sumber penghidupannya terganggu cenderung menurun. Sebagai pembanding, rumah tangga yang sumber penghidupannya tidak terganggu/

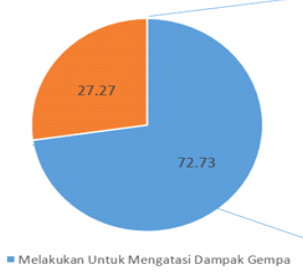

\begin{tabular}{l|r}
\hline $\begin{array}{l}\text { Iindakan yang dilakukan untuk mengatasi sumber } \\
\text { pendapatan keluarga }\end{array}$ & \multicolumn{1}{c|}{ Total } \\
\hline A. Jual aset/harta yang ada & 10,18 \\
\hline B. meminjam uang & 35,71 \\
\hline C. mengurangi konsumsi & 21,25 \\
\hline D. Menambah jumlah anggota keluarga untuk bekerja & \\
\hline E. Menitipkan anggota keluarga ke keluarga lain & 0,07 \\
\hline F. Berganti pekerjaan & 0,54 \\
G. Anggota keluarga menjadi TKI & 9,46 \\
H. Lainnya & 2,86 \\
& 6,96
\end{tabular}

Sumber: Pengolahan Data Mentah, UNDP, 2019

Gambar 5. Strategi Untuk Mengatasi Dampak Gempa Terhadap Sumber Pendapatan Keluarga

(Jawaban Dapat Lebih Dari 1)

terdampak di Kabupaten Sumbawa dan Kabupaten Sumbawa Barat, rerata pendapatan pasca gempa 2018 adalah naik sedangkan pendapatan keluarga di kabupaten lainya cenderung menurun.

Penurunan jumlah pendapatan keluarga yang terdampak gempa mempengaruhi pola pengeluaran yang ada. Secara merata di semua kabupaten/ kota terdampak gempa, pengeluaran keluarga yang dominan yaitu kiriman ke keluarga, sandang seperti baju, celana, sepatu sarung, makanan pokok seperti pangan dan lauk pauk serta pendidikan. Ada kecenderungan kiriman ke keluarga

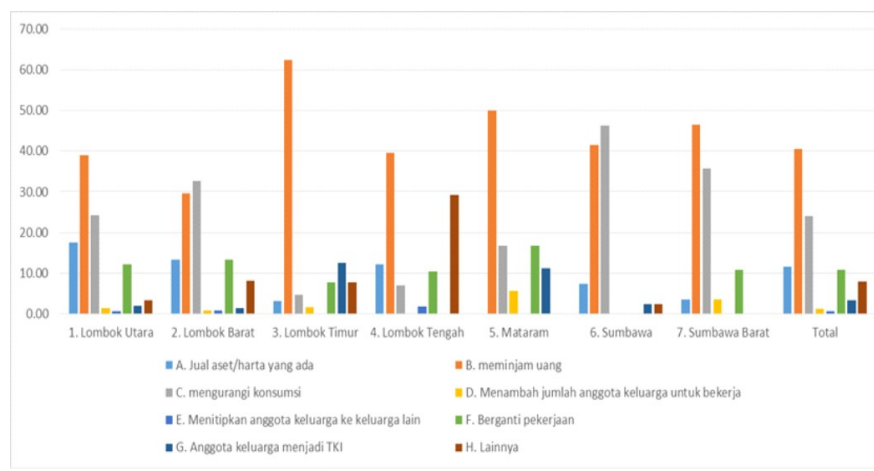

Sumber: Pengolahan Data Mentah, UNDP, 2019

Grambar 6. Strategi Untuk Mengatasi Dampak Gempa

Terhadap Sumber Pendapatan Keluarga Per Kabupaten (Jawaban Bisa Lebih Dari 1) mengalami kenaikan setelah gempa, seperti Kabupaten Lombok Utara, Kota Mataram dan Kabupaten Sumbawa Barat. Sedangkan pengeluaran untuk makanan, sandang, pendidikan dan lain-lain cenderung mengalami penurunan hampir di semua kabupaten/ kota terdampak.

Selain itu, jaringan sosial yang dimiliki oleh keluarga, juga salah satu yang memberikan pengaruh terhadap keluarga dalam mendapatkan dukungan untuk mempertahankan sumber penghidupan. Sebelum dan setelah gempa 2018, bantuan yang diterima keluarga sebagian besar berasal dari pemerintah, dalam berbagai macam bentuknya. Di Kabupaten Lombok Utara misalnya setelah gempa bantuan dari pemerintah naik dari 8,07 \% menjadi $12,56 \%$ berupa dana tunai. Selain bantuan dari pemerintah, responden menyatakan bantuan dari keluarga menempati peringkat kedua dari berbagai macam sumber bantuan. Selain itu bantuan berupa makanan banyak diberikan oleh lembaga internasional terutama setelah bencana (pasca bencana). Secara keseluruhan untuk Kota Mataram, Kabupaten Sumbawa, dan Kabupaten Sumbawa Barat bantuan eksternal hanya mengalami sedikit kenaikan terutama pada jenis bantuan uang tunai, transfer, dan sembako dari pemerintah.

Analiss sumber penghidupan memberkuat dalam memetakan akses, aset, dan mengetahui mata pencaharian yang paling strategis serta menarik bagi masyarakat (Serrat \& Serrat, 2017). Strategi pilihan sumber penghidupan ini memberi variasi pilihan strategi dan juga distribusi yang beragam dalam kelompok masyarakat dan variasi di wilayah gempa yang ada di wilayah Lombok dan Sumbawa. Rumah tangga selalu mencari usaha lain untuk mencari sumber pendapatan seperti menjual asset, mencari dukungan dari jaringan sosial ada dan ini sejalan dengaan pendapat Chambers (1995) dan Hussein \& Nelson (1998). Sebagian rumah tangga yang memilih untuk migrasi untuk mencari sumber penghidupan menjadi TKI ini juga relevan dengan temuan Loebach (2016) yang mencatat migrasi sebagai salah satu strategi sumber penghidupan pasca bencana. Meskipun dalam kasus badai Katerina yang di Amerika pilihan migrasi lebih banyak dilakukan oleh seluruh anggota rumah tangga, sementara dalam kasus bencana Lombok dan Sumbaya, pelaku migran ini hanya sebagian dari anggota rumah tangga, sementara anggota rumah tangga yang lain bertahan di Lombok dan Sumbawa.

\section{KESIMPULAN}

Gempa bumi bumi Lombok dan Sumbawa 2018 telah memberikan berbagai dampak. Di tingkat rumah tangga terutama yang terkait dengan sumber penghidupan, gempa bumi Lombok dan Sumbawa memberi dampak kehilangan aset rumah tangga dan aset produktif terutama aset-aset bangunan. Dampak bervariasi antar kabupaten/kota, dampak terbesar dialami di Lombok Utara dan Barat. Selain berdampak terkait dengan aset produktif dan non-produktif rumah tangga, gempa bumi juga telah memberikan dampak bagi $74,3 \%$ sumber penghidupan korban. Hanya tercatat 25,7 \% menyatakan bahwa sumber penghidupan mereka tidak terganggu. Akibat gempa bumi ini, dampak yang paling besar dialami oleh rumah tangga adalah berkurangnya pendapatan, kehilangan pekerjaan, berkurangnya kemampuan fisik untuk bekerja, hilangnya pemasok, dan pasar, dampak bervariasi antar kabupaten/kota. Untuk mengatasi gangguan terhadap sumber penghidupan, 
kegiatan/upaya yang dilakukan oleh keluarga penyintas adalah meminjam, mengurangi konsumsi, menjual aset, atau mendapatkan dukungan dari eksternal. Variasi cara mengatasi gangguan terhadap sumber penghidupan rumah tangga ini adalah bervariasi antar kabupaten.

Gempa telah memberikan dampak bagi sumber penghidupan korban, namun demikian dari studi ini menunjukkan bahwa korban gempa relatif memiliki mekanisme untuk mengatasi dampak gempa terhadap sumber penghidupan mereka. Termasuk di dalamnya tidak mengantungkan sumber pendapatan dari satu sumber, memanfaatkan jaringan sosial dan keluarga termasuk mendapatkan kiriman dari luar. Hasil studi ini menunjukan bahwa rata-rata kiriman dari keluarga lebih tinggi setelah gempa dibandingkan sebelum gempa.

Gempa memberi gangguan kepada aset rumah tangga meskipun tidak semua rumah tangga tidak terganggu sumber penghidupannya. Kajian lebih lanjut adanya perbedaan gangguan terhadap sumber penghidupan dan faktor yang memngaruhinya penting dilakukan terutama untuk memberikan dukungan pemulihan sumber penghidupan pasca bencana.

\section{UCAPAN TERIMA KASIH}

Penulis mengucapkan banyak terima kasih kepada Andrys Erawan, Zaenudin Zaen, Rinto Andriono dari UNDP, pengurus dan enumerator dari LSM Gema Alam, Sahabat Bumi, Somasi, Yayasan mandiri yang telah membantu dan mendukung dalam pengumpulan data di lapangan.

\section{KONTRIBUSI PENULIS}

Kedua penulis terlibat dalam proses design penelitian, pengumpulan data, analisis, dan penulisan

\section{DAFTAR PUSTAKA}

Armenian, H. K., Melkonian, A., Nojl, E. K., \& Hovanesian, A. P. (1997). Deaths and injuries due to the earthquake in Armenia: A cohort approach. International Journal of Epidemiolo$g y$. https://doi.org/10.1093/ije/26.4.806

Ashley, C., \& Hussein, K. (2000). Developing methodologies for Livelihood Impact Assessment: Experiences of the African Wildlife Foundation in East Africa. Overseas Development Institute.

Bappenas. (2018). Kajian dan Analisis Dampak Bencana Gempa Lombok (Dipresentasikan Di Bappeda Provinsi NTB. 5-7 Oktober 2018).

BPS. (2019). Statistik Hotel Bintang dan Non Bintang Bulan Desember 2018 Di Nusa Tanggara Barat (Berita Resmi Statistik Perhotelan; No. 09/02/52/Th.XIII, 1 Pebruari 2019). https:// ntb.bps.go.id/pressrelease/download.

Chambers, R., \& Conway, G. R. (1992). Sustainable rural livelihoods: practical concepts for the 21st century. IDS Discussion Paper.

Chambers, Robert. (1995). Poverty and livelihoods: Whose reality counts? Environment \& Urbanization. 7(1), 173-204 https:// doi.org/10.1177/095624789500700106

Chou, Y. J., Huang, N., Lee, C. H., Tsai, S. L., Chen, L. S., \& Chang, H. J. (2004). Who is at risk of death in an earthquake? American Journal of Epidemiology. 160(7), 688-695 https:// doi.org/10.1093/aje/kwh270

de Haan, L., \& Zoomers, A. (2005). Exploring the frontier of livelihoods research. Development and Change. https:// doi.org/10.1111/j.0012-155X.2005.00401.x

DFID. (1999). Sustainable livelihoods guidance sheets. The frame- work. Department for International Development.

Ellidokuz, H., Ucku, R., Aydin, U. Y., \& Ellidokuz, E. (2005). Risk factors for death and injuries in earthquake: Cross-sectional study from Afyon, Turkey. Croatian Medical Journal.

Ellis, F. (2000). The determinants of rural livelihood diversification in developing countries. Journal of Agricultural Economics. https://doi.org/10.1111/j.1477-9552.2000.tb01229.x

Hussein, K., \& Nelson, J. (1998). Sustainable Livelihoods And Livelihood Diversification. 대한내과학회지. 69(4), 32. http:// opc-prd.ubib.eur.nl:8080/DB $=\quad 3 / \mathrm{LNG}=\quad \mathrm{EN} / \mathrm{PPN}$ ? PPN=236411659/

King, B. (2011). Spatialising livelihoods: Resource access and livelihood spaces in South Africa. Transactions of the Institute of British Geographers. 36(2), 297-313 https://doi.org/10.1111/ j.1475-5661.2010.00423.x

Knutsson, P. (2006). The sustainable livelihoods approach: A framework for knowledge integration assessment. Human Ecology Review. 13. 90-99

Loebach, P. (2016). Household migration as a livelihood adaptation in response to a natural disaster: Nicaragua and Hurricane Mitch. Population and Environment. 38(2), 185-206 https:// doi.org/10.1007/s11111-016-0256-9

Osaki, Y., \& Minowa, M. (2001). Factors associated with earthquake deaths in the great Hanshin-Awaji earthquake, 1995. American Journal of Epidemiology. 153(2), 153-156 https:// doi.org/10.1093/aje/153.2.153

Rofi, A. (2006). Kematian Terkait Gempa Bumi 27 Mei 2006 Di Kabupaten Klaten Jawa Tengah. Populasi, 17(2), 191-199.

Sanderson, D. (2000). Cities, disasters and livelihoods. Environment and Urbanization. 12(2), 93-102. https:// doi.org/10.1177/095624780001200208

Scoones, I. (1998). Sustainable rural livelihoods: a framework for analysis. IDS Working Paper.

Serrat, O., \& Serrat, O. (2017). The Sustainable Livelihoods Approach. In Knowledge Solutions. hal 21-26. https:// doi.org/10.1007/978-981-10-0983-9_5

Wei, B., Su, G., Qi, W., \& Sun, L. (2016). The livelihood vulnerability of rural households in earthquake-stricken areas-A case study of Ning'er, Yunnan Province. Sustainability (Switzerland). https://doi.org/10.3390/su8060566

Wisner, B, Blaikie, P., Cannon, T., \& Davis, I. (2004). At Risk: Natural Hazards. People's Vulnerability and Disasters. August. Hal 3-20. http://www.preventionweb.net/files/670_72351.pdf

Wisner, Ben, Blaikie, P., Cannon, T., \& Davis, I. (2014). At risk: natural hazards, peoples vulnerability and disasters. dalam $A t$ Risk: Natural Hazards Peoples Vulnerability and Disasters. https://doi.org/10.4324/9780203714775 